\title{
KEPRAKTISAN BAHAN AJAR PERENCANAAN PEMBELAJARAN BERBASIS PENDIDIKAN KARAKTER DAN SAINTIFIK
}

\author{
Zahra Alwi $^{1}$, Ernalida ${ }^{2}$, Yenni Lidyawati ${ }^{3}$ \\ Prodi Pend. Bahasa dan Sastra Indonesia FKIP Universitas Sriwijaya Indonesia \\ zahra_alwi@fkip.unsri.ac.id
}

\begin{abstract}
ABSTRAK: Perencanaan Pembelajaran merupakan matakuliah wajib yang harus diikuti oleh mahasiswa program studi pendidikan Bahasa dan Sastra Indonesia FKIP Universitas Sriwijaya pada semester enam. Matakuliah tersebut memberikan panduan untuk calon guru dalam membuat perangkat pembelajaran dan meyimulasikannya. Untuk mengetahui kepraktisan buku ajar Perencanaan Pembelajaran Bahasa Berbasis Pendidikan karakter dan Pendekatan Saintifik (PPBPKPS) yang sudah dikembangkan dan divalidasi oleh para ahli dan sudah diterbitkan cetakan pertama, perlu diketahui, "Bagaimanakah kepraktisan buku PPBPKPS, dilihat dari uji one-to-one dan uji small grup? Metode yang digunakan, bagian dari penelitian dan pengembanganfase keempat, deskriptif kuantitatif. Subjek penelitiannya adalah mahasiswa semester 6 kelas Inderalaya dan kelas Palembang, teknik pengumpulan data menggunakan angket, wawancara, dan tes, analisis data yang digunakan adalah analisis statistik deskriptif. Tingkat kepraktisan yang digunakan mengacu pada kriteria berikut ini. 1) tidak praktis (0-54), 2) kurang praktis (55-59), 3) cukup praktis $(60-75), 4)$ praktis $(76-85)$, dan 5) sangat praktis $(86-100)$. Dari uji kepraktisanbahan ajar PPBPKPS, terlihat dari 4 aspek yang terpenuhi yakni: efektif, kreatif, efisien, dan menarik. Hasil nilai kepraktisan dari data one to one diperoleh rata-rata nilai 80.05 dan dari small grup diperoleh rata-rata 81,03, berarti bahan ajar ini tergolong praktis. Selanjutnya bahan ajar tersebut dapat digunakan oleh mahasiswa dalam kegiatan perkuliahan dan oleh guru di lapangan.
\end{abstract}

KATA KUNCI: Bahan Ajar; Karakter; Kepraktisan; Saintifik.

\section{PRACTICES OF TEACHING MATERIALS LEARNING BASED ON CHARACTER AND SAINTIFIC EDUCATION}

\begin{abstract}
Learning Planning is a compulsory subject that must be attended by students of the Indonesian Language and Literature education program FKIP Sriwijaya University in the sixth semester. The course provides guidance for prospective teachers in making learning tools and simulating them. To find out the practicality of textbooks based on Character Learning and Scientific Approaches (PPBPKPS) that have been developed and validated by experts and published the first print, the problem is, "What is the practicality of the PPBPKPS book, seen from the one-to-one test and the small group test? The method used is part of research and development, the fourth phase. The research subjects were 6th semester students of Inderalaya and Palembang classes, data collection techniques using questionnaires, interviews, and tests, the data analysis used was descriptive statistical analysis. The level of practicality used refers to the following criteria. 1) impractical (0-54), 2) rather-practical (55-59), 3) quite practical $(60-75), 4)$ practical $(76-85)$, and 5) very practical (86-100). From the practicality test of PPBPKPS teaching materials, it can be seen from 4 aspects that are fulfilled namely: effective, creative, efficient, and interesting, the results of practicality values from one to one data obtained an average value of 80.05 and from the small group an average of 81.03 means this teaching material is classified as practical. Furthermore, these teaching materials can be used by students in lecturing activities and by teachers in the field.
\end{abstract}

KEYWORDS: Teaching Material; Practicality; Character, Scientific

\begin{tabular}{lccc}
\hline Diterima: & Direvisi: & Disetujui: & Dipublikasi: \\
11-12-2019 & 06-03-2020 & $07-03-2020$ & $31-03-2020$ \\
Pustaka & : Alwi, Z., Ernalida, \& Lidyawati, Y. (2020). KEPRAKTISAN BAHAN AJAR \\
\multicolumn{4}{r}{ PERENCANAAN PEMBELAJARAN BERBASIS PENDIDIKAN KARAKTER DAN } \\
& SAINTIFIK. Fon: Jurnal Pendidikan Bahasa dan Sastra Indonesia, 16(1), 10-21. \\
\hline
\end{tabular}




\section{PENDAHULUAN}

Pendidikan yang dilaksanakan di sekolah selain dituntut untuk memaksimalkan keterampilan dan kemampuan kognitif, hal yang tidak kalah penting adalah memberikan pendidikan karakter. Pendidikan karakter sangat penting untuk menyeimbangkan antar kecakapan yang didapat.Karakter adalah sifat kejiwaan, budi pekerti, atau akhlak yang melekat dan menjadi ciri khas seseorang atau sekelompok orang (Majid, Abdul dan Dian Andayani, 2010). Dalam (Djamarah, 2010) dinyatakan, pendidikan karakter merupakan upaya yang sungguhsungguh untuk mempelajari, memahami, membentuk, dan menumbuhkan nilainilai etika, baik untuk pribadi maupun untuk kelompok dan semua warga masyarakat atau warga negara secara keseluruhan. Jika para dosen sudah mengajarkan kurikulum secara komprehensif melalui konsep, teori, metodologi dan aplikasi setiap bidang studi, maka kebermaknaan yang diajarkannya akan lebih efektif dalam menunjang pendidikan karakter (Alwi, 2017). Dalam Zubaedi (2011) dinyatakan, pendidikan karakter adalah usaha yang sungguh-sungguh untuk memahami, membentuk, memupuk nilai-nilai etika, baik untuk diri sendiri maupun untuk semua warga masyarakat atau warga negara secara keseluruhan.

Pendidikan karakter menurut Lickona mengandung tiga unsur pokok, yaitu mengetahui kebaikan (knowing the good), mencintai kebaikan (desiring the good), dan melakukan kebaikan (doing the good) (Akhwan, 2011). Pendidikan karakter tidak sekedar mengajarkan mana yang benar dan mana yang salah kepada anak, tetapi lebih dari itu pendidikan karakter menanamkan kebiasaan (habituation) tentang yang baik sehingga peserta didik paham, mampu merasakan, dan mau melakukan yang baik. Pendidikan karakter ini membawa misi yang sama dengan pendidikan akhlak atau pendidikan moral.

Pendidikan karakter hendaknya dirumuskan dalam kurikulum, diterapkan dalam metode pendidikan, dan dipraktekkan dalam pembelajaran. Selain itu, di lingkungan keluarga dan masyarakat sekitar juga sebaiknya diterapkan pola pendidikan karakter.Hal itu sudah dirumuskan dalam tujuan pembangunan Indonesia, dalam tujuan pendidikan Nasional, dan diperjelas lagi dalam kurikulum 2013.

Adapun pendekatan saintifik dimaksudkan untuk memberikan pemahaman kepada peserta didik dalam mengenal, memahami berbagai materi menggunakan pendekatan ilmiah, bahwa informasi bisa berasal dari mana saja, kapan saja, tidak bergantung pada informasi searah dari guru. Oleh karena itu kondisi pembelajaran yang diharapkan tercipta diarahkan untuk mendorong peserta didik dalam mencari tahu dari berbagai sumber melalui observasi, dan bukan hanya diberi tahu.

Sehubungan dengan istilah tersebut, (Permatasari, 2014) menyatakan bahwa pendekatan saintifik merupakan pendekatan keilmuan yang bersifat logis dan sistematis. Dalam prosesnya diawali dari siswa menanya, karena ada objek yang dilihat dan didengar maka siswa merespon sehingga muncul kegiatan bertanya, ketika guru menyampaikan atau menjawab pertanyaan dari siswa maka nantinya akan dikaitkan dengan materi yang diajarkan. Kemudian siswa diajak untuk menyelesaikan persoalan-persoalan dengan cara berkolaborasi dalam suatu kelompok misalnya dengan diskusi antar siswa satu dengan lainnya. Dalam hal ini harus bersifat merata dan tidak berpihak pada salah satu kelompok saja. Sehingga akan muncul keterampilan-keterampilan yang diperoleh peserta didik seperti, menghargai pendapat orang lain, dan juga kompetensi mempresentasikan. 


\section{Perencanaan}

Pembelajaran merupakan matakuliah wajib yang harus diikuti oleh mahasiswa program studi pendidikan Bahasa dan Sastra Indonesia FKIP Universitas Sriwijaya pada semester lima. Mata kuliah ini bertujuan memberikan kompetensi kepada mahasiswa untuk memahami hakikat perencanaan pengajaran bahasa, modelmodel pengajaran bahasa dan sastra Indonesia, perumusan tujuan pengajaran, pemilihan materi pembelajaran, pemilihan media/strategi/pendekatan, metode, teknik pengajaran, dan pengembangan evaluasi pengajaran. Capaian pembelajaran dari matakuliah ini adalah mahasiswa mampu menyusun dan menerapkan perangkat pembelajaran.

Perencanaan pembelajaran memiliki bobot 3 SKS dengan Sembilan materi perkuliahan yang meliputi hakikat perencanaan pembelajaran, pendidikan karakter dan pendekatan saintifik, fungsi perencanaan pembelaaran, prinsip-prinsip perencanaan pembelaaran, model-model perencanaan pembelaaran bahasa, kinerja guru: kompetensi dasar mengajar, kompetensi guru dan kompetensi guru professional, konsep manfaat, tujuan, prinsip, format dan langkah penyusunan RPP, penilaian perangkat perencanaan dan pelaksanaan pembelajaran: IPKG 1 dan IPKG 2, dan contoh RPP bahasa Indonesia SMP dan SMA yang berbasis pendidikan karakter dan pendekatan saintifik. Agar perkuliahan perencanaan pembelajaran dapat berjalan sesuai dengan Rencana Pembelajaran Semester (RPS), maka harus dibantu dengan bahan ajar. Bahan ajar yang digunakan harus dirancang berdasarkan kebutuhan. Hal ini perlu dilakukan sejalan dengan pendapat (Cunningsworth, 1995), yaitu untuk mempersiapkan serangkaian tujuan pembelajaran yang diarahkan bagi kebutuhan peserta didik.Untuk itu telah dihasilkan Buku Perencanaan Pembelajaran
Bahasa
Berbasis Pendidikan Karakter dan Pendekatan Saintifik (PPBPKPS), yang sudah diterbitkan cetakan pertama oleh penerbit Noerfikri, dengan ISBN 978-62391205-4-2.

Bahan ajar perencanaan pembelajaran tersebut telah diuji kelayakannya oleh dua orang pakar yang berasal dari latar belakang bahasa dan pendidikan bahasa Indonesia. Secara keseluruhan bahan perencanaan pembelajaran ini sudah sangat valid, kelayakan isi dengan nilai rata-rata 80,55 , aspek kelayakan penyajian didapatkan 77,40, aspek kelayakan kebahasaan dengan nilai rata-rata 92,30 , dan didapat nilai rata-rata 83,41 .

Untuk mengetahui apakah Buku PPBPKPS yang sudah dihasilkan, divalidasi, dan diterbitkan tersebut sudah memiliki kepraktisan, perlu dilakukan uji kepraktisan melalui uji one-to-one dan uji small grup. Hal ini sesuai dengan pendapat (Carey, 2015), bahwa untuk menilai materi yang sudah dikembangkan dan melakukan perbaikan, perlu dilakukan uji perorangan dan uji kelompok kecil.

Praktikalitas berkaitan dengan keterpakaian bahan perkuliahan oleh pengguna yaitu mahasiswa dan dosen serta ahli lainnya.menyatakan bahwa praktikalitas harus mempertimbangkan indikator kejelasan, berguna, dan hemat biaya. (Jan, 2013) Selain itu, (Fauzan, 2002) mengungkapkan bahwa dalam menguji tingkat kepraktisan sebuah bahan ajar harus mempertimbangkan apakah produk menarik dan bisa digunakan. Berdasarkan pendapat ahli maka indikator kepraktisan yang digunakan adalah kemudahan penggunaan, daya tarik, dan efisiensi. Hal ini sejalan juga dengan penelitian Agustyaningrum (2017, hlm. 414), menyimpulkan bahwa praktikalitas merupakan tingkat keterpakaian atau kemudahan bahan ajar untuk digunakan oleh mahasiswa, meliputi: aspek kemudahan penggunaan dan aspek 
penyajian. Aspek kemudahan penggunaan meliputi kemudahan memahami materi dan bahasa yang digunakan dalam modul. Sedangkan aspek penyajian fokus pada tampilan modul.

Berbeda dengan yang sudah dilakukan Agustyaningrum, dalam pengujian yang peneliti lakukan, selain memperhatikan aspek-aspek kemudahan dan penyajian, ditambahkan juga penilaian terhadap efisiensi. Sebagaimana dinyakatan Nugraha, dkk (2013, Hlm. 2) bahwa perubahan yang cepat dalam berbagai bidang kehidupan menuntut mahasiswa/siswa untuk memilih, mengolah, dan mendapatkan informasi dari berbagai sumber yang efektif dan efisien. Jadi bahan ajar yang dihasilkan harus efisien.

\section{METODE}

Metode yang digunakan dalam penelitian ini deskriptif kuantitatif, merupakan bagian dari penelitian dan pengembangan, mengacu teori (Gall, Meredith D, Gall, Joice P \& Walter Borg, 2007) dan (Richey, Rita C and James D Klein, 1997). Secara keluruhan ada 5 tahap untuk menjawab 5 rumusan masalah, tetapi dalam tulisan ini dilaporkan hasil dari tahap 4, menjawab satu dari 5 permasalahan yang diajukan, yaitu pertanyaan keempat, "Bagaimanakah kepraktisan bahan ajar Perencanaan Pembelajaran Bahasa Berbasis Pendidikan Karakter dan Pendekatan Saintifik yang sudah dikembangkan?"

Subjek penelitian ini adalah mahasiswa Program Studi Pendidikan Bahasa Indonesia semester 6 tahun ajaran 2018/2019, berjumlah 15 orang.

Teknik pengumpulan data menggunakan angket, wawancara, dan tes. Angket disusun sesuai skala Likert, dengan 4 alternatif pilihan jawaban. (Creswell 1014), menyatakan "Questionnaires, are for used in a survey design that participant in a study complete and return to the researcher." Angket berisi pernyataan-pernyataan mengenai kelayakan buku Perencanaan Pembelajaran Bahasa berbasis Pendidikan Karakter dan Pendekatan Saintifik yang sudah dihasilkan/dikembangkan. Tes berbentuk pilihan ganda sebanyak 10 soal yang menguji kemampuan mahasiswa setelah menggunakan buku yang dihasilkan.

Data yang diperoleh dari hasil tes, wawancara, dan angket dianalisis dan dideskripsikan secara kualitatif dan kuantitatif. Analisis data yang digunakan adalah analisis statistik deskriptif.

Teknik analisis data yang digunakan adalah analisis statistik deskriptif.Adapun tingkat kepraktisan mengacu pada kriteria berikut ini. 1) tidak praktis $(0-54), 2)$ kurang praktis (55-59), 3) cukup praktis $(60-75)$, 4) praktis $(76-85)$, dan 5) sangat praktis (86-100), dimodifikasi dari (Afrizon, 2019).

\section{HASIL DAN PEMBAHASAN}

Bahan ajar dalam bentuk buku PPBPKPS, yang sudah diterbitkan ini, telah diuji kepraktisannya dengan uji satu satu (one to one evaluation) dan uji kelompok kecil (small grup evaluation). Berikut hasil dan pembahasannya.

\section{Hasil uji satu satu (one to one evaluation)}

Untuk melihat kepraktisan buku PPBPKPS ini, telah dilakukan uji perorangan atau uji satu satu (one to one evaluation), pada hari Rabu, 14 Agustus 2019, yang dilakukan dengan mahasiswa semester 6 Universitas Sriwijaya sebanyak 3 orang mahasiswa. Tiga orang mahasiswa tersebut dipilih berdasarkan nilai pretest yang diperoleh, yaitu 1 mahasiswa dengan kemampuan tinggi, 1 mahasiwa dengan kemampuan sedang, dan 1 mahasiswa dengan kemampuan rendah. Hal ini sejalan dengan teori yang dikemukakan Carey (2015, Hlm. 288), 
The purpose of the first stage of formative evaluation, the one-toone evaluation stage, is to identify and remove the most obvious errors in the instruction and to obtain initial performance indications and reactions to the content by learners. During this stage of direct interaction between the designer and individual learners, the designer works individually with three or more learners who are representative of the target population.

Masing-masing mahasiwa mengisi angket yang telah disediakan. Mahasiswa memberi penilaian pada 4 komponen yang terdiri dari: (1) efektif, (2) kreatif, (3) efisien, (4) menarik. Skor maksimal dalam evaluasi ini adalah 89.7 dengan kriteria sangat praktis.

Berikut ini uraian hasil evaluasi perorangan atau uji satu satu (one to one evaluation) dilakukan oleh mahasiswa (BSH) pada setiap komponen, yaitu pada komponen materi efektif memperoleh skor 2,9 (praktis), pada aspek kreatif, memperoleh skor 2,8 (praktis), pada aspek efisien, memperoleh skor 3,2 (praktis), pada aspek menarik, memperoleh skor 3,0 (praktis). Hasil evaluasi perorangan atau uji satu satu (one to one evaluation) dilakukan oleh mahasiswa pertama (BSH), secara keseluruhan skor yang diperoleh adalah 2.97 termasuk kriteria praktis. Adapun komentar dan saran yang diberikan pada bahan ajar perencanaan pembelajaran berbasis pendidikan karak-ter dan pendekatan saintifik sudah sangat baik dan sangat mudah dipahami. Buku perencanaan pembelajaran berbasis pendidikan karakter dan pendekatan saintifik tersebut juga lebih memotivasi untuk giat dalam belajar.Saran yang diberikan ada gambar yang kurang jelas, seharusnya gambarnya sudah lebih jelas.

Uraian hasil evaluasi perorangan (one to one evaluation) yang dilakukan oleh mahasiswa kedua ( $\mathrm{Z}$ ) pada setiap aspek, yaitu pada aspek efektif memperoleh skor 3.0 (praktis), pada aspek kreatif mempeoleh skor 2,9 (praktis), pada aspek efisien memperoleh skor 3,1 (praktis), pada aspek menarik memperoleh skor 3,3 (prkatis). Hasil evaluasi perorangan atau one to one evaluation dilakukan oleh mahasiswa Z, secara keseluruahn skor yang diperoleh adala 3.07 dikriteriakan praktis. Komentar dan saran yang diberikannya terhadap bahan ajar perencanaan pembelajaran berbasis pendidikan karakter dan pendekatan saintifik sudah sangat baik dan mudah untuk dipahami. Buku perencanaan pembelajaran berbasis pendidikan karakter dan pendekatan saintifik juga lebih memotivasi untuk lebih giat dalam belajar. Saran yang diberikan oleh Z, "Ada soal yang rumit dan panjang membuat saya bosan, jadi soal jangan panjang-panjang”. Saran tersebut sudah dipertimbangkan dan sudah dilakukan revisi.

Berikut ini hasil evaluasi perorangan (one to one evaluation) yang dilakukan oleh mahasiswa (ES) pada setiap aspek, yaitu pada aspek efektif memperoleh skor 3.4 (praktis), pada aspek kreatif memperoleh skor 3,2 (praktis), pada aspek efisien memperoleh skor 3,0 (praktis), pada aspek menarik memperoleh skor 2,9 (praktis). Hasil evaluasi perorangan atau uji satu satu (one to one evaluation) dilakukan oleh mahasiswa (ES) secara keseluruhan skor yang diperoleh adalah 3.12 dikriteriakan praktis.

Adapun komentar dan saran yang diberikan ES terhadap bahan ajar perencanaan pembelajaran berbasis pendidikan karakter dan pendekatan saintifik ini sudah cukup baik dan mudah dimengerti. Buku perencanaan pembelajaran berbasis 
pendidikan karakter dan pendekatan saintifik ini menjelaskan pengertian, contoh, dan ciri-ciri sehingga belajarnya lebih mudah dimengerti.

Berikut rangkuman hasil evaluasi uji satu satu (one to one evaluation)

Tabel 1. Rekapitulasi Hasil Uji Satu Satu (One To One Evaluation)

\begin{tabular}{|l|l|l|l|}
\hline No. & $\begin{array}{c}\text { Nama } \\
\text { mahasiswa }\end{array}$ & Skor & \multicolumn{1}{|c|}{ Kriteria } \\
\hline 1 & BSH & 80,07 & Praktis \\
\hline 2 & Z & 84,07 & Praktis \\
\hline 3 & ES & 85,07 & Praktis \\
\hline
\end{tabular}

Masing-masing mahasiwa mengisi angket yang telah disediakan. Mahasiswa memberi penilaian pada 4 komponen yang terdiri dari, yaitu (1) efektif, (2) kreatif, (3) efisien, (4) menarik.Skor maksimal dalam evaluasi ini adalah 89.7 dengan kriteria sangat praktis.

\section{Evaluasi kelompok kecil (small group evaluation)}

Evaluasi kelompok kecil (small group evaluation) dilakukan pada hari Rabu, 21 Agustus 2019 berdasarkan evaluasi small group atau kelompok kecil evaluasi tersebut dilakukan dengan mahasiswa semester 6 Universitas Sriwijaya sebanyak 15 mahasiswa. Lima belas mahasiswa tersebut dipilih berdasarkan nilai bahasa Indonesia yang diperoleh, yaitu 5 mahasiswa dengan kemampuan tinggi, 5 mahasiswa dengan kemampuan sedang, 5 mahasiswa dengan kemampuan rendah. Masing-masing mahasiwa mengisi angket yang telah disediakan. Hal ini sejalan dengan pendapat (Carey, 2015), bahwa untuk mengetahui kelayakan materi yang sudah dikembangkan, perlu dilakukan small grup evaluation.

Mahasiswa memberi penilaian pada 4 aspek yang terdiri dari (1) kreatif, (2) efektif, (3) efisien dan (4) menarik. Skor maksimal dalam evaluasi ini adalah 100 dengan kriteria sangat praktis. Berikut deskripsi hasil uji kelompok kecil.

Hasil evaluasi kelompok kecil (small group) yang dilakukan oleh mahasiswa pertama (Y) pada setiap aspek, yaitu (1) kreatif, memperoleh skor 80 (praktis), pada aspek (2) efektif, memperoleh skor 77 (praktis), pada aspek (3) efisien memperoleh skor 82 (praktis), pada aspek (4) menarik memperoleh skor 81 (praktis). Hasil evaluasi kelompok kecil (small group) dilakukan oleh mahasiswa (Y) secara keseluruhan skor yang diperoleh adalah 80 dikriteriakan praktis. Adapun komentar dan saran yang diberikan pada bahan ajar perencanaan pembelajaran berbasis pendidikan karakter dan pendekatan saintifik ini sudah sangat baik dan mudah dimengerti. Buku bahan ajar perencanaan pembelajaran berbasis pendidikan karakter dan pendekatan saintifik tersebut juga lebih memotivasi untuk lebih giat dalam belajar. Saran yang diberikan "Penambahan gambarnya harus lebih bervariasi".

Uraian evaluasi kelompok kecil (small group) dilakukan oleh mahasiswa kedua (YD) pada setiap aspek, yaitu (1) kreatif memperoleh skor 79 (praktis), pada aspek (2) efektif memperoleh skor 83 (praktis), pada aspek (3) efisien memperoleh skor 80 (praktis), pada aspek (4) menarik memperoleh skor 78 (praktis). Hasil evaluasi kelompok kecil (small group) dilakukan oleh mahasiswa (YD) secara keseluruhan skor yang diperoleh adalah 80 dikriteriakan praktis. Adapun komentar dan saran yang diberikan pada bahan ajar perencanaan pembelajaran berbasis pendidikan karakter dan pendekatan saintifik ini sudah sangat baik dan mudah dimengerti. Buku bahan ajar perencanaan pembel-ajaran berbasis pendidikan karakter dan pendekatan saintifik tersebut juga lebih memotivasi untuk lebih giat dalam belajar. Saran yang 
diberikan "Pemilihan gambar pada karangan deskripsi kurang menarik".

Uraian hasil evaluasi

kelompok kecil (small group) dilakukan oleh mahasiswa ketiga (BA) pada setiap aspek , yaitu (1) kreatif memperoleh skor 82 (praktis), pada aspek (2) efektif memperoleh skor 80 (praktis), pada aspek (3) efisien memperoleh skor 84 (praktis), pada aspek (4) menarik memperoleh skor 81 (praktis). Hasil evaluasi kelompok kecil (small group) dilakukan oleh mahasiswa (BA) secara keseluruhan skor yang diperoleh adalah 81.75 dikriteriakan praktis. Adapun komentar dan saran yang diberikan pada bahan ajar perencanaan pembelajaran berbasis pendidikan karakter dan pendekatan saintifik ini sudah sangat baik dan mudah dimengerti. Buku bahan ajar perencanaan pembelajaran berbasis pendidikan karakter dan pendekatan saintifik tersebut juga lebih memotivasi untuk lebih giat dalam belajar. Saran yang diberikan "Gambar harus lebih jelas lagi”.

Berikut ini uraian evaluasi kelompok kecil (small group) dilakukan oleh mahasiswa keempat (DPR) pada setiap aspek, yaitu (1) kreatif memperoleh skor 80 (praktis), pada aspek (2) efektif memperoleh skor 78 (praktis), pada aspek (3)efisien memperoleh skor 83 (praktis), pada aspek (4) menarik memperoleh skor 84 (praktis). Hasil evaluasi kelompok kecil (small group) dilakukan oleh mahasiswa (DPR) secara keseluruhan skor yang diperoleh adalah 81.25 dikriteriakan praktis. Adapun komentar dan saran yang diberikan pada bahan ajar perencanaan pembelajaran berbasis pendidikan karakter dan pendekatan saintifik ini sudah sangat baik dan mudah dimengerti. Buku bahan ajar perencanaan pembelajaran berbasis pendidikan karakter dan pendekatan saintifik tersebut juga lebih memotivasi untuk lebih giat dalam belajar. Saran yang diberikan "Penggunaan gambar mempermudah dalam belajar".

Uraian evaluasi kelompok kecil (small group) dilakukan oleh mahasiswa kelima (A) pada setiap aspek, yaitu kreatif memperoleh skor 84 (praktis), pada aspek efektif memperoleh skor 80 (praktis), pada aspek efisien memperoleh skor 83 (praktis), pada aspek efisien memperoleh skor 81 (prkatis), pada aspek menarik memperoleh skor 79 (praktis). Hasil evaluasi kelompok kecil (small group) dilakukan oleh mahasiswa (A) secara keseluruhan skor yang diperoleh adalah 82 dikriteriakan praktis. Adapun komentar dan saran yang diberikan pada bahan ajar perencanaan pembelajaran berbasis pendidikan karakter dan pendekatan saintifik ini sudah sangat baik dan mudah dimengerti. Buku bahan ajar perencanaan pembelajaran berbasis pendidikan karakter dan pendekatan saintifik tersebut juga lebih memotivasi untuk lebih giat dalam belajar. Saran yang diberikan "Soal yang disediakan sangat mudah dimengerti".

Berikut ini uraian evaluasi kelompok kecil (small group) dilakukan oleh mahasiswa keenam (F) pada setiap aspek, yaitu (1) kreatif memperoleh skor 84 (praktis), pada aspek (2) efektif memperoleh skor 80 (praktis), pada aspek (3) efisien memperoleh skor 83 (praktis), pada aspek (4) menarik memperoleh skor 77 (praktis). Hasil evaluasi kelompok kecil (small group) dilakukan oleh mahasiswa (F) secara keseluruhan skor yang diperoleh adalah 81 dikriteriakan praktis. Adapun komentar dan saran yang diberikan pada bahan ajar perencanaan pembelajaran berbasis pendidikan karakter dan pendekatan saintifik ini sudah sangat baik dan mudah dimengerti. Buku bahan ajar perencanaan pembelajaran berbasis pendidikan karakter dan pendekatan saintifik tersebut juga lebih memotivasi untuk lebih giat dalam belajar. 
Saran yang diberikan "Soal latihan diperbanyak agar lebih cepat dipahami".

Uraian hasil evaluasi kelompok kecil (small group) dilakukan oleh mahasiswa ketujuh (AM) pada setiap aspek, yaitu (1) kreatif memperoleh skor 81 (praktis), pada aspek (2) efektif memperoleh skor 80 (praktis), pada aspek (3) efisien memperoleh skor 84 (praktis), pada aspek (4) menarik memperoleh skor 79 (praktis). Hasil evaluasi kelompok kecil (small group) dilakukan oleh mahasiswa (AM) secara keseluruhan skor yang diperoleh adalah 81 dikriteriakan praktis. Adapun komentar dan saran yang diberikan pada bahan ajar perencanaan pembelajaran berbasis pendidikan karakter dan pendekatan saintifik ini sudah sangat baik dan mudah dimengerti. Buku bahan ajar perencanaan pembelajaran berbasis pendidikan karakter dan pendekatan saintifik tersebut juga lebih memotivasi untuk lebih giat dalam belajar. Saran yang diberikan "Uraian materinya perlu lebih dikongkritkan lagi".

Berikut ini uraian evaluasi kelompok kecil (small group) dilakukan oleh mahasiswa kedelapan (EP) pada setiap aspek, yaitu (1) kreatif memperoleh skor 84 (praktis), pada aspek (2) efektif memperoleh skor 81 (praktis), pada aspek (3) efisien memperoleh skor 83 (praktis), pada aspek (4) menarik memperoleh skor 79 (praktis). Hasil evaluasi kelompok kecil (small group) dilakukan oleh mahasiswa (EP) secara keseluruhan skor yang diperoleh adalah 81.7 dikriteriakan praktis. Adapun komentar dan saran yang diberikan pada bahan ajar perencanaan pembelajaran berbasis pendidikan karakter dan pendekatan saintifik ini sudah sangat baik dan mudah dimengerti. Buku bahan ajar perencanaan pembelajaran berbasis pendidikan karakter dan pendekatan saintifik tersebut juga lebih memotivasi untuk lebih giat dalam belajar. Saran yang diberikan "Soal latihan diperbanyak agar lebih cepat dipahami".

Uraian hasil evaluasi kelompok kecil (small group) dilakukan oleh mahasiswa kesembilan (Z) pada setiap aspek, yaitu (1) bkreatif memperoleh skor 84 (praktis), pada aspek (2) efektif memperoleh skor 80 (praktis), pada aspek (3) efisien memperoleh skor 80 (praktis), pada aspek (4) menarik memperoleh skor 79 (praktis). Hasil evaluasi kelompok kecil (small group) dilakukan oleh mahasiswa (Z) secara keseluruhan skor yang diperoleh adalah 80.75 dikriteriakan praktis. Adapun komentar dan saran yang diberikan pada bahan ajar perencanaan pembelajaran berbasis pendidikan karakter dan pendekatan saintifik ini sudah sangat baik dan mudah dimengerti. Buku bahan ajar perencanaan pembelajaran berbasis pendidikan karakter dan pendekatan saintifik tersebut juga lebih memotivasi untuk lebih giat dalam belajar. Komentar yang diberikan "Soal latihan bagus, cepat dipahami”.

Hasil evaluasi kelompok kecil (small group) yang dilakukan oleh mahasiswa kesepuluh (DAO) pada setiap aspek, yaitu (1) kreatif memperoleh skor 84 (praktis), pada aspek (2) efektif memperoleh skor 83 (praktis), pada aspek (3) efisien memperoleh skor 83 (praktis), pada aspek (4) menarik memperoleh skor 79 (praktis). Hasil evaluasi kelompok kecil (small group) dilakukan oleh mahasiswa (DAO) secara keseluruhan skor yang diperoleh adalah 82.25 dikriteriakan praktis. Adapun komentar dan saran yang diberikan pada bahan ajar perencanaan pembelajaran berbasis pendidikan karakter dan pendekatan saintifik ini sudah sangat baik dan mudah dimengerti. Buku bahan ajar perencanaan pembelajaran berbasis pendidikan karakter dan pendekatan saintifik tersebut juga lebih memotivasi untuk lebih giat dalam belajar. Komentar yang diberikan "Bahasa dalam soalnya mudah dipahami". 
Uraian hasil evaluasi kelompok kecil (small group) dilakukan oleh mahasiswa kesebelas (ES) pada setiap aspek, yaitu (1) kreatif memperoleh skor 82 (praktis), pada aspek (2) efektif memperoleh skor 80 (praktis), pada aspek (3) efisien memperoleh skor 84 (praktis), pada aspek (4) menarik memperoleh skor 78 (praktis). Hasil evaluasi kelompok kecil (small group) dilakukan oleh mahasiswa (ES) secara keseluruhan skor yang diperoleh adalah 81 dikriteriakan praktis. Adapun komentar dan saran yang diberikan pada bahan ajar perencanaan pembelajaran berbasis pendidikan karakter dan pendekatan saintifik ini sudah sangat baik dan mudah dimengerti. Buku bahan ajar perencanaan pembelajaran berbasis pendidikan karakter dan pendekatan saintifik tersebut juga lebih memotivasi untuk lebih giat dalam belajar. Saran yang diberikan "Pembahasan dalam materinya dibuat lebih menarik".

Berikut ini uraian evaluasi kelompok kecil (small group) dilakukan oleh mahasiswa kedua belas (AES) pada setiap aspek, yaitu (1) kreatif memperoleh skor 84 (praktis), pada aspek (2) efektif memperoleh skor 80 (praktis), pada aspek (3) efisien memperoleh skor 85 (praktis), pada aspek (4) menarik memperoleh skor 84 (praktis). Hasil evaluasi kelompok kecil (small group) dilakukan oleh mahasiswa (AES) secara keseluruhan skor yang diperoleh adalah 83.2 dikriteriakan praktis. Adapun komentar dan saran yang diberikan pada bahan ajar perencanaan pembelajaran berbasis pendidikan karakter dan pendekatan saintifik ini sudah sangat baik dan mudah dimengerti. Buku bahan ajar perencanaan pembelajaran berbasis pendidikan karakter dan pendekatan saintifik tersebut juga lebih memotivasi untuk lebih giat dalam belajar. Komentar yang diberikan "Pembahasan materinya cepat dimengerti".
Berikut ini uraian evaluasi kelompok kecil (small group) dilakukan oleh mahasiswa ketiga belas (AYS) pada setiap aspek, yaitu (1) kreatif memperoleh skor 84 (praktis), pada aspek (2) efektif memperoleh skor 80 (praktis), pada aspek (3) efisien memperoleh skor 83 (praktis), pada aspek (4) menarik memperoleh skor 87 (praktis). Hasil evaluasi kelompok kecil (small group) dilakukan oleh mahasiswa (AYS) secara keseluruhan skor yang diperoleh adalah 83.5 dikriteriakan praktis. Adapun komentar dan saran yang diberikan pada bahan ajar perencanaan pembelajaran berbasis pendidikan karakter dan pendekatan saintifik ini sudah sangat baik dan mudah dimengerti. Buku bahan ajar perencanaan pembelajaran berbasis pendidikan karakter dan pendekatan saintifik tersebut juga lebih memotivasi untuk lebih giat dalam belajar. Saran yang diberikan "Materinya disusun lebih terinci dan terarah".

Berikut ini uraian evaluasi kelompok kecil (small group) dilakukan oleh mahasiswa keempat belas (BK) pada setiap aspek, yaitu (1) kreatif memperoleh skor 83 (praktis), pada aspek (2) efektif memperoleh skor 80 (praktis), (3) efisien memperoleh skor 78 (prkatis), pada aspek (4) menarik memperoleh skor 77 (praktis). Hasil evaluasi kelompok kecil (small group) dilakukan oleh mahasiswa (BK) secara keseluruhan skor yang diperoleh adalah 79.5 dikriteriakan praktis. Adapun komentar dan saran yang diberikan pada bahan ajar perencanaan pembelajaran berbasis pendidikan karakter dan pendekatan saintifik ini sudah sangat baik dan mudah dimengerti. Buku bahan ajar perencanaan pembelajaran berbasis pendidikan karakter dan pendekatan saintifik tersebut juga lebih memotivasi untuk lebih giat dalam belajar. Saran yang diberikan "Soal latihan dan materi dibuat lebih menarik lagi untuk dipelajari". 
Berikut ini uraian evaluasi kelompok kecil (small group) dilakukan oleh mahasiswa kelima belas (SI) pada setiap aspek, yaitu (1) kreatif memperoleh skor 80 (praktis), pada aspek (2) efektif memperoleh skor 80 (praktis), pada aspek (3) efisien memperoleh skor 83 (praktis), pada aspek (4) menarik memperoleh skor 77 (praktis). Hasil evaluasi kelompok kecil (small group) dilakukan oleh mahasiswa (SI) secara keseluruhan skor yang diperoleh adalah 80 dikriteriakan praktis. Adapun komentar dan saran yang diberikan pada bahan ajar perencanaan pembelajaran berbasis pendidikan karakter dan pendekatan saintifik ini sudah sangat baik dan mudah dimengerti. Buku bahan ajar perencanaan pembelajaran berbasis pendidikan karakter dan pendekatan saintifik tersebut juga lebih memotivasi untuk lebih giat dalam belajar. Saran yang diberikan "Materi akan lebih baik dan mudah dipahami dan dilengkapi dengan gambar".

Tabel 2. Rekapitulasi Nilai Hasil Uji Kelompok Kecil (Small Group)

\begin{tabular}{|l|l|c|c|}
\hline No. & Nama & Skor & Kriteria \\
\hline 1 & Y & 80 & Praktis \\
\hline 2 & YD & 80 & Praktis \\
\hline 3 & BA & 81,75 & Praktis \\
\hline 4 & DPR & 81,75 & Praktis \\
\hline 5 & A & 82 & Praktis \\
\hline 6 & F & 81 & Praktis \\
\hline 7 & AM & 79 & Praktis \\
\hline 8 & EP & 81,75 & Praktis \\
\hline 9 & Z & 80,75 & Praktis \\
\hline 10 & DAO & 82,25 & Praktis \\
\hline 11 & ES & 81 & Praktis \\
\hline 12 & AES & 83.2 & Praktis \\
\hline 13 & AYS & 83,5 & Praktis \\
\hline 14 & BK & 79,5 & Praktis \\
\hline 15 & SI & 80 & Praktis \\
\hline & Rata-rata & 81,03 & Praktis \\
\hline
\end{tabular}

Berdasarkan nilai kepraktisan dari data EJI small group diperoleh rata-rata 75.49 berarti Bahan ajar ini tergolong praktis, artinya bahan ajar ini agar bisa digunakan oleh mahasiswa dalam kegiatan perkuliahan. Jika dilihat dari masingmasing aspek, aspek efisien memperoleh nilai tertinggi yaitu 89.7 , sedangkan pada aspek kreatif memperoleh nilai terendah yaitu 81.5.

Beberapa saran yang menjadi pertimbangan dalam perbaikan bahan ajar ini adalah menambahkan model-model pembelajaran yang relevan dengan kemajuan zaman, penggunaan huruf dan tata letak yang lebih menarik, dan penjelasan pada bahan ajar lebih detil lagi.Berikut adalah diagram penilaian hasil kepraktisan uji kelompok kecil (Small Group).

Gambar 1. Grafik batang hasil uji small group

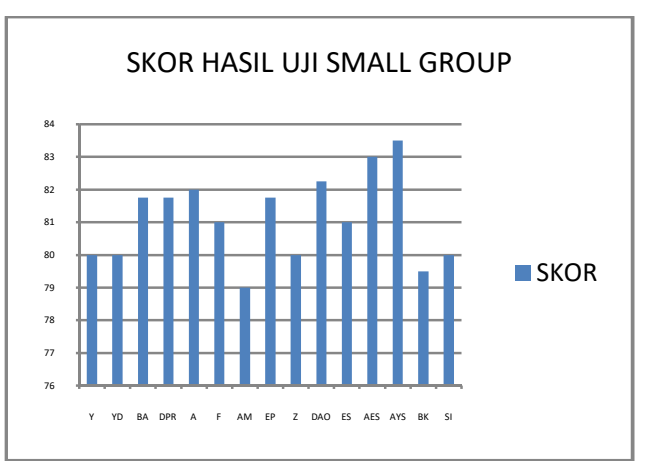

Dari grafik di atas, terlihat hasil uji kelompok kecil, menunjukkan bahwa nilai kepraktisan dari data small group diperoleh rata-rata 81,03 berarti bahan ajar ini tergolong praktis. Dari 15 mahasiswa sampel diperileh nilai tertinggi yaitu 83,5, sedangkan nilai terendah yaitu 79 . Ini artinya bahan ajar ini dapat digunakan oleh mahasiswa dalam kegiatan perkuliahan dan dapat juga dijadikan panduan oleh guru di lapangan.

Bahan ajar ini telah diujicobakan melalui uji perorangan dan uji kelompok kecil. Hasilnya menunjukkan bahwa buku 
PPBPKPS yang sudah diterbitkan ini memiliki tingkat kerpaktisan, tergolong praktis, dan dapat digunakan dalam perkuliahan. Hal ini sejalan denganpendapat Jan, bahwa praktikalitas berkaitan dengan keterpakaian bahan perkuliahan oleh pengguna yaitu mahasiswa dan dosen serta ahli lainnya. Jan menyatakan bahwa praktikalitas harus mempertimbangkan indikator kejelasan, berguna, dan hemat biaya. (Jan, 2013).

Penilaian juga telah dilakukan sesuai teori (Carey, 2015), bahwa untuk mengetahui kepraktisan materi yang dikembangkan, harus melalui uji satusatu (one-to-one evaluation) dan uji kelompok kecil (small group evaluation). Tahap yang dilakukan sudah sesuai dengan prosedur, yaitu diawali dengan uji satu-satu menggunakan angket, selanjutnya dilakukan uji kelompok kecil dengan instrumen tes dan angket. Hasilnya menunjukkan bahwa hasil analisis dari uji one-to-one dan hasil uji small groupsejalan, sama-sama menunjukkan bahwa bahan ajar ini tergolong praktis.

Hasil penelitian dan pengembangan ini juga selaras dengan teori yang dikemukakan (Fauzan, 2002), bahwa dalam menguji tingkat kepraktisan sebuah bahan ajar harus mempertimbangkan apakah produk menarik dan bisa digunakan. Indikator penilaian uji kepraktisan yang digunakan adalah kemudahan penggunaan, daya tarik dan efisiensi, sesuai dengan pendapat ahli tersebut. Hasilnya juga menunjukkan bahwa bahan ajar yang dihasilkan memiliki daya tarik karena terdapat variasi warna, ada gambar, dan grafik, tidak hanya dipenuhi oleh teks. Bahan ajar ini juga praktis dan mudah penggunaannya. Rachmadani dkk (2019, Hlm. 38-39) juga telah melakukan penelitian pengembangan bahan ajar untuk SMA dengan prosedur penilaian yang sama, meliputi uji validasi, uji kepraktisan, dan uji keefektifan. Hanya penggunaan istilahnya yang berbeda, metode penelitiannya mengacu teori Sugiyono.

Berasarkan hasil wawancara diperoleh berapa saran yang menjadi pertimbangan dalam perbaikan bahan ajar ini, yaitu perlu menambahkan model-model pembelajaran yang relevan dengan kemajuan zaman, perlu ditambahkan kunci jawaban soal yang disertai pembahasan lengkap supaya mahasiswa/ pembaca dapat mengkaji sendiri setiap soal/tugas dan jawabannya, perlu merevisi penggunaan huruf dan tata letak supaya lebih menarik, dan perlu penjelasan pada bahan ajar yang lebih rinci lagi. Secara keseluruhan isi buku ini sudah sistematik dan lengkap, tetapi perlu dilakukan revisi, khususnya dalam teknik penulisan.

\section{KESIMPULAN}

Berdasarkan hasil penelitian dan pembahasan yang telah dilakukan, diperoleh kesimpulan bahwa bahan ajar Perencanaan Pembelajaran Bahasa Berbasis Pendidikan Karakter dan Pendekatan Saintifik memiliki tingkat kepraktisan dengan rata-rata uji one to one sebesar 80 dan hasil uji small group sebesar 81,3. Jadi dapat disimpulkan bahwa Buku Ajar Perencanaan Pembelajaran Bahasa yang sudah dikembangkan dan diuji kepraktisannya ini telah praktis digunakan di dalam perkuliahan semester genap 2019. Disarankan agar buku ini dapat dijadikan rujukan di program studi lain, atau bahkan di perguruan tinggi lain, dan dapat dijadikan acuan bagi guru di lapangan. Bagi peneliti selanjutnya, disarankan agar dapat melakukan penelitian sejenis dalam mata kuliah yang berbeda atau melanjutkan penelitian ini dengan melakukan uji efektivitas. 


\section{DAFTAR PUSTAKA}

Afrizon, Renol, Wahyuni Satria Dewi. (2019). Kepraktisan Bahan Ajar Statistika Pendidikan Fisika Bermuatan Model Cooperative Problem Solving. Jurnal Eksakta Pendidikan.

Agustyaningrum, Nina, Yesi Gusmania. (2017). "Praktikalitas dan Keefektifan Modul Geometri analitik Ruang Berbasis Konstruktivisme"Jurnal Dimensi. Diakses 13 Januari 2020.

Akhwan, M. (2011). Pendidikan Karakter: Konsep dan Implemen-tasinya dalam Pembelajaran di Sekolah/ Madrasah. Makalah disajikan dalam diskusi dosen Fakultas Ilmu Agama Islam UII.

Alwi, Z. (2017). Pengembangan Bahan Ajar Syair Berbasis Kearifan Lokal:Modul dan Compact Disk untuk Kelas IX MTs di Kota Palembang. Disertasi Palem-bang: UIN Raden Fatah.

Creswell, John W. (2014). Educational Research, Planning, Conducting, and Evaluating Quantitative and Qualitative Research. Englewood Cliff, New Jersey: Pearson Merill Prentice Hall.

Cunningsworth, Alan. (1995). Choosing Your Coursebook. Oxford: Heinemann Publishers Ltd.

Djamarah, S. B. (2010). Guru dan Anak Didik dalam Interaksi Edukatif suatu Pendekatan Teoretir Psikologis. Jakarta: Rineka Cipta.

Dick, Walter, and Lou Carey. (2015). The Sistematic Design of Instruction. Eigth edition. New York: Harper Collins Colledge Publishers.

Fauzan, A. (2002).Applying Realistic Mathematics Education (RME) in Teaching Geometry in Indonesian
PrimarySchools. Thesis.University of Twente, Enshcede.

Gall, Meredith D. Joyce P. Gall, and Walter R. Borg, Educational Research Introduction.Eighth Edition. (2007). USA: Pearson Education, Inc.

Jan van den Akker, Brenda Bannan, Anthony E. Kelly. Nienke Nieveen, Tjeerd Plomp. (2013). Educational Design Research Part A: Introduction. Netherlands Institute for Curriculum Development (SLO), Enschede, the Netherlands

Majid, Abdul dan Dian Andayani. (2010). Pendidikan Karakter dalam Perspektif Islam. Bandung: Insan Cita Utama.

Nugraha, Danu Aji, Achmad Binadja, Supartono. (2013). "PengembanganBahan Ajar ReaksiRedoksBervisisets, BerorientasiKonstruktivistik"Journal of Innovative Science Education.

Permatasari, E. A. (2014). Implementasi Pendekatan Saintifik dalam Kurikulum 2013 pada Pembelajaran Sejarah. International Journal of History Education Vol. 3 No. 1, 11--16.

Rahmadani, Nurhesti, Ade MTD, dan Rosmawati H. (2019). "Pengembangan Bahan Ajar Teks Eksplanasi pada Siswa Kelas X SMA" .FON Jurnal Pendidikan Bahasa dan Sastra Indonesia, Vol.15, No.2, 2019.

Richey, Rita C. and James D. Klein. (1997). Desain and Development Research. New York, Routledge.

Zubaedi. (2011). Design Pendidikan Karakter. Jakarta: Prenada Media Group. 